\title{
Participation of Ethnic Community Towani Tolotang in Deliberation of Development Plan
}

\author{
Ahmad Mustanir \\ Dept. of Government \\ The Social and Political Science College Muhammadiyah Rappang \\ Sidrap - South Sulawesi, Indonesia \\ ahmadmustanir74@gmail.com
}

\author{
Partisan Abadi \\ The Social and Political Science College \\ Muhammadiyah Rappang \\ Sidrap - South Sulawesi, Indonesia
}

\author{
Nasri A \\ The Social and Political Science College \\ Muhammadiyah Rappang \\ Sidrap - South Sulawesi, Indonesia
}

\begin{abstract}
This research is essential to find out how the community, particularly the ethnic group of Towani Tolotang, participates in the deliberation of development plan. According to the results of the observation, the involvement of community participation especially in deliberation of development plan is very low. It is indicated by a few numbers of residents who are invited and attend the deliberation. Understanding the objectives and problems will be beneficial in determining how the ethnic group of Towani Tolotang participate in deliberation. For that purpose, the methods required to find out the answers are through observation, questionnaires, interviews and literature studies related to the research topic. By looking at the indicators of the deliberation of development plan such as the community participation throughout attendance, involvement in planning, policy making, accountability, monitoring, assessment, and utilization of development products, the results of the research are qualified as unfavorable with average percentage of $48,6 \%$.
\end{abstract}

Keywords: Community Participation, Towani Tolotang, Deliberation of Development Plan

\section{INTRODUCTION}

Throughout the preliminary observation conducted in Kanyuara showed that Participatory approach in planning through the mechanism of deliberation of development plan remains rhetoric. Development planning is still dominated by government policy, because people, especially ethnic group of Towani Tolotang still has very minimal involvement.

Participation based on Law No.25 of 2004 concerning The National Development Planning System (as one of the objectives of SPPN within article 2 paragraph 4 (d) defined "Public participation as the participation of the community to accommodate their interests in the formulation of development plans". From the previous definition, public participation is the involvement or participation of a person in the processes of social interactions, identification of the problem and potential in the community within certain situations, whether in decision-making (solutions) to handle the problem, the implementation of problem solving and community engagement process in evaluating the changes.

Whereas in Kanyuara, in District of Sidenreng Rappang, the involvement of community participation especially in deliberation of development plan is very low. It is indicated by a few numbers of residents who are invited and attend the deliberation. The last deliberation of development plan was only attended by the representatives of Gapoktan as group of farmers representing the element of society.

According to [1], Participation of community members is the involvement of community members in development include activities in the planning and execution (implementation) of program / project development performed in the community. Meanwhile, according to [2], Community participation in development is defined as community participation in the development, participation in development activities and participation in utilizing and enjoying the results of the development. Study on the definition of community participation [3] addressed the scope of participation by starting with the sequence of the development planning process, the type of community participation in development as follows: 1) Participation in decision-making, 2) participation in the implementation of activities, 3) participation in the monitoring and evaluation of development, 4) participation in the utilization of development outcomes.

Participations of ethnic group of Towani Tolotang in deliberation of development plan consist of community participation throughout attendance, involvement in planning, policy making, accountability, monitoring, assessment, and utilization of development products which are the core of this research. 


\section{METHOD}

The type of research is descriptive research aiming to provide a clear picture of a phenomenon or social reality concerning the problems examined [4], particularly concerning the participation of ethnic group of Towani Tolotang in Village of Kanyuara. Techniques used to collect data in this research were observation, questionnaire, interview, and library research.

Data analysis techniques will be classified, analyzed and interpreted in detail, carefully and thoroughly to obtain more objective conclusion of a study.

The data analysis in this research will be conducted thoroughly as an effort to find and systematically organize the record of the results of observations, interviews, questionnaires and other information to improve the understanding of the researchers of the cases studied. The analysis model uses the help of the frequency table, using a likert scale as a measure to draw conclusions.

\section{RESULT AND DISCUSSION}

TABLE. 1. Attendance in Deliberation of Development Plan

\begin{tabular}{|c|c|c|c|c|c|}
\hline No. & Answer & Weight & Frequency & Score & Percentage \\
\hline 1 & always & 4 & 12 & 48 & 13 \\
\hline 2 & often & 3 & 15 & 45 & 16 \\
\hline 3 & rarely & 2 & 31 & 62 & 33 \\
\hline 4 & never & 1 & 40 & 40 & 38 \\
\hline \multicolumn{2}{|c|}{$\begin{array}{c}\text { Average } \\
\text { score }\end{array}$} & \multicolumn{2}{|c|}{$\begin{array}{c}\text { Total score } \\
\text { Total respondents }\end{array}$} & $\frac{195}{98}$ & 1.99 \\
\hline \multicolumn{2}{|c|}{$\begin{array}{c}\text { Average of } \\
\text { percentage }\end{array}$} & \multicolumn{2}{|c|}{ Average score } \\
The Highest weight
\end{tabular}

Source: Data that has been processed, 2016

The table above shows that $13 \%$ of respondents say always taking a part, $16 \%$ of respondents say often playing a role, while $33 \%$ of respondents say rarely taking a part and $38 \%$ of respondents say never taking a role. It can be concluded that the presence of the community in deliberation of development plan at Kanyuara village is approximately $49.7 \%$ in the unfavorable category.

TABLE. 2. Community Participation in Deliberation of Development Plan

\begin{tabular}{|c|c|c|c|c|c|}
\hline No. & Answer & Weight & Frequency & Score & Percentage \\
\hline 1 & always & 4 & 13 & 52 & 18 \\
\hline 2 & often & 3 & 14 & 42 & 14 \\
\hline 3 & rarely & 2 & 30 & 60 & 31 \\
\hline 4 & never & 1 & 41 & 41 & 37 \\
\hline \multicolumn{2}{|c|}{ Average score } & \multicolumn{2}{|c|}{$\frac{\text { Total score }}{\text { Total respondents }}$} & $\frac{195}{98}$ & 1.99 \\
\hline \multicolumn{2}{|c|}{$\begin{array}{l}\text { Average of } \\
\text { percentage }\end{array}$} & \multicolumn{2}{|c|}{$\frac{\text { Average score }}{\text { The Highest weight }}$} & $\mathrm{x} 100 \%$ & $\begin{array}{cl}1.99 & x 100 \\
4 & =49.7\end{array}$ \\
\hline
\end{tabular}

Source: Data that has been processed, 2016

The table above shows that $18 \%$ of respondents say always taking a part, $14 \%$ of respondents regard often taking a role, whilst $31 \%$ of respondents say rarely playing a role and $37 \%$ of respondents state never partaking. It can be concluded that the role of the community in deliberation of development plan in the Kanyuara village is around $49.7 \%$ in low category of taking a role.

TABLE. 3. Involvement in Development Policy Making

\begin{tabular}{|c|c|c|c|c|c|}
\hline No. & Answer & Weight & Frequency & Score & Percentage \\
\hline 1 & always & 4 & 11 & 44 & 16 \\
\hline 2 & often & 3 & 15 & 45 & 15 \\
\hline 3 & rarely & 2 & 31 & 62 & 32 \\
\hline 4 & never & 1 & 41 & 41 & 37 \\
\hline \multicolumn{2}{|c|}{ Average score } & \multicolumn{2}{|c|}{$\frac{\text { Total score }}{\text { Total respondents }}$} & $\frac{192}{98}$ & 1.96 \\
\hline \multicolumn{2}{|c|}{$\begin{array}{l}\text { Average of } \\
\text { percentage }\end{array}$} & \multicolumn{2}{|c|}{$\begin{array}{c}\text { Average score } \\
\text { The Highest weight }\end{array}$} & $\mathrm{x} 100 \%$ & $\begin{array}{cc}1.96 & \mathrm{x} 100 \\
& =49.0\end{array}$ \\
\hline
\end{tabular}

Source: Data that has been processed, 2016

The table above shows that $16 \%$ of respondents say always taking a part, $15 \%$ of respondents regard often taking a role, whilst $32 \%$ of respondents say rarely playing a role and $37 \%$ of respondents state never partaking. It can be concluded that the role of the community in deliberation of development plan in the Kanyuara village is around $49.0 \%$ in low category of taking a role.

TABLE. 4. Responsibility Towards the Planning and Outcomes of the Development

\begin{tabular}{|c|c|c|c|c|c|}
\hline No. & Answer & Weight & Frequency & Score & Percentage \\
\hline 1 & always & 4 & 10 & 40 & 15 \\
\hline 2 & often & 3 & 14 & 42 & 14 \\
\hline 3 & rarely & 2 & 33 & 66 & 34 \\
\hline 4 & never & 1 & 41 & 41 & 37 \\
\hline \multicolumn{2}{|c|}{ Average score } & \multicolumn{2}{|c|}{$\begin{array}{c}\text { Total score } \\
\text { Total respondents }\end{array}$} & $\frac{189}{98}$ & 1.93 \\
\hline \multicolumn{2}{|c|}{$\begin{array}{c}\text { Average of } \\
\text { percentage }\end{array}$} & \multicolumn{2}{|c|}{ Average score } \\
The Highest weight
\end{tabular}

Source: Data that has been processed, 2016

The table above shows that $15 \%$ of respondents say always taking a part, $14 \%$ of respondents regard often taking a role, whilst $34 \%$ of respondents say rarely playing a role and $37 \%$ of respondents state never partaking. It can be concluded that the role of the community in deliberation of development plan in the Kanyuara village is around $48.2 \%$ in low category of taking a role.

TABLE. 5. Monitoring Participation Towards the Outcomes of the Development

\begin{tabular}{|c|c|c|c|c|c|}
\hline No. & Answer & Weight & Frequency & Score & Percentage \\
\hline 1 & always & 4 & 9 & 36 & 14 \\
\hline 2 & often & 3 & 15 & 45 & 15 \\
\hline 3 & rarely & 2 & 33 & 66 & 34 \\
\hline 4 & never & 1 & 41 & 41 & 37 \\
\hline Average score & \multicolumn{2}{|c|}{$\begin{array}{c}\text { Total score } \\
\text { Total respondents }\end{array}$} & $\frac{188}{98}$ & 1.92 \\
\hline \multicolumn{2}{|c|}{$\begin{array}{c}\text { Average of } \\
\text { percentage }\end{array}$} & \multicolumn{2}{|c|}{$\begin{array}{c}\text { Average score } \\
\text { The Highest weight }\end{array}$} & x100\% & $1.92 \quad \begin{array}{c}\times 100 \\
=48.0\end{array}$ \\
\cline { 4 - 6 }
\end{tabular}


Source: Data that has been processed, 2016

The table above shows that $14 \%$ of respondents say always taking a part, $15 \%$ of respondents regard often taking a role, whilst $34 \%$ of respondents say rarely playing a role and $37 \%$ of respondents state never partaking. It can be concluded that the role of the community in deliberation of development plan in the Kanyuara village is around $48.0 \%$ in low category of taking a role.

TABLE. 6. Assessment Towards Deliberation Activities of Development Plan and the Outcomes of the Development

\begin{tabular}{|c|c|c|c|c|c|}
\hline No. & Answer & Weight & Frequency & Score & Percentage \\
\hline 1 & always & 4 & 9 & 36 & 14 \\
\hline 2 & often & 3 & 15 & 45 & 15 \\
\hline 3 & rarely & 2 & 33 & 66 & 34 \\
\hline 4 & never & 1 & 41 & 41 & 37 \\
\hline \multicolumn{2}{|c|}{$\begin{array}{c}\text { Average } \\
\text { score }\end{array}$} & \multicolumn{2}{|c|}{$\begin{array}{c}\text { Total score } \\
\text { Total respondents }\end{array}$} & $\frac{188}{98}$ & 1.92 \\
\hline \multicolumn{2}{|c|}{$\begin{array}{c}\text { Average of } \\
\text { percentage }\end{array}$} & \multicolumn{2}{|c|}{$\begin{array}{c}\text { Average score } \\
\text { The Highest weight }\end{array}$} & x100\% & $1.92 \quad \begin{array}{l}\text { x } 100 \\
=48.0\end{array}$ \\
\hline
\end{tabular}

Source: Data that has been processed, 2016

The table above shows that $14 \%$ of respondents say always taking a part, $15 \%$ of respondents regard often taking a role, whilst $34 \%$ of respondents say rarely playing a role and $37 \%$ of respondents state never partaking. It can be concluded that the role of the community in deliberation of development plan in the Kanyuara village is around $48.0 \%$ in low category of taking a role.

TABLE. 7. Utilization of the Outcomes of the Development

\begin{tabular}{|c|c|c|c|c|c|}
\hline No. & Answer & Weight & Frequency & Score & Percentage \\
\hline 1 & always & 4 & 10 & 40 & 29 \\
\hline 2 & often & 3 & 14 & 42 & 13 \\
\hline 3 & rarely & 2 & 31 & 62 & 25 \\
\hline 4 & never & 1 & 43 & 43 & 33 \\
\hline \multicolumn{2}{|c|}{ Average score } & \multicolumn{2}{|c|}{$\begin{array}{c}\text { Total score } \\
\text { Total respondents }\end{array}$} & $\frac{187}{98}$ & 1.91 \\
\hline \multicolumn{2}{|c|}{$\begin{array}{c}\text { Average of } \\
\text { percentage }\end{array}$} & \multicolumn{2}{|c|}{ Average score } \\
The Highest weight
\end{tabular}

Source: Data that has been processed, 2016

The table above shows that $29 \%$ of respondents say always taking a part, $13 \%$ of respondents regard often taking a role, whilst $25 \%$ of respondents say rarely playing a role and $33 \%$ of respondents state never partaking. It can be concluded that the role of the community in deliberation of development plan in the Kanyuara village is around $47.7 \%$ in low category of taking a role.

TABLE. 8. Recapitulation of Indicators on Community Participation of Ethnic Towani Tolotang

In Deliberation of Development Plan

\begin{tabular}{|c|l|c|}
\hline No. & \multicolumn{1}{|c|}{ Indicator } & Percentage \\
\hline 1 & $\begin{array}{l}\text { Attendance of Ethnic Group of Towani } \\
\text { Tolotang in Deliberation of } \\
\text { Development Plan }\end{array}$ & $49.7 \%$ \\
\hline 2 & Community Participation of Ethnic & $49.7 \%$ \\
\hline
\end{tabular}

\begin{tabular}{|c|l|c|}
\hline & $\begin{array}{l}\text { Group of Towani Tolotang in } \\
\text { Deliberation of Development Plan }\end{array}$ & \\
\hline 3 & $\begin{array}{l}\text { Involvement of Ethnic of Towani } \\
\text { Tolotang in Development Policy } \\
\text { Making }\end{array}$ & $49.0 \%$ \\
\hline 4 & $\begin{array}{l}\text { Responsibility of Ethnic of Towani } \\
\text { Tolotang towards the planning and } \\
\text { outcomes of the development }\end{array}$ & $48.2 \%$ \\
\hline 5 & $\begin{array}{l}\text { Monitoring Participation of Ethnic of } \\
\text { Towani Tolotang towards the outcomes } \\
\text { of the development }\end{array}$ & $48.0 \%$ \\
\hline 6 & $\begin{array}{l}\text { Assessment by Ethnic of Towani } \\
\text { Tolotang towards deliberation activities } \\
\text { of development plan and the outcomes } \\
\text { of the development }\end{array}$ & $48.0 \%$ \\
\hline 7 & $\begin{array}{l}\text { Utilization of the outcomes of the } \\
\text { development by ethnic of Towani } \\
\text { Tolotang }\end{array}$ & $47.7 \%$ \\
\hline \multicolumn{1}{|c|}{ Recapitulation } & $48.6 \%$ \\
\hline
\end{tabular}

Source: Data that has been processed, 2016

The processed data obtained by observing the indicators of the community participation considering their attendance in Deliberation of Development Plan, their involvement in the development planning, involvement in policy making, responsibility towards the outcomes of the deliberation of development plan, assessment towards the deliberation of development plan and its outcomes, as well as the utilization of the outcomes of the development plan. Therefore, it shows that the community participation of ethnic group of Towani Tolotang in the Village of Kanyuara in District of Sidenreng Rappang (Sidrap) in the deliberation of development plan is still classified as unfavorable with the average percentage of $48,6 \%$.

Social concept which must be held down by every resident of the community and participation in deliberation is a development plan social activities in the life of ethnic Towani Tolotang which also considered the worship of the Gods. But this is not very good effect on people's participation in the deliberation development plan. This is also due to ethnic Towani Tolotang the majority in Kanyuara village more listening to what the ethnic leader "Uwa and Uwata" as the highest authority in which every activity is controlled based on the existing rules of their ancestors, than what is conveyed head of the village are not an ethnic Towani Tolotang.

\section{CONCLUSION}

There are several important discoveries referring to the results of the discussion in the previous section concerning the participation of ethnic group of Towani Tolotang. The results show that the community participation of ethnic group of Towani Tolotang in the Village of Kanyuara in District of Sidenreng Rappang (Sidrap) in the deliberation of development plan is still classified as unfavorable with the average percentage of $48,6 \%$. It is based on the community attendance at the deliberation of development plan, involvement in planning, involvement in policy making, responsibility towards the outcomes of the deliberation of development plan, 
assessment towards the deliberation of development plan and its outcomes, as well as the utilization of the outcomes of the development plan.

\section{REFERENCES}

[1] Adisasmita, Raharjo. Building Participative Village. Yogyakarta: Graha Ilmu. 2006.

[2] Slamet, Y. Basic Concepts of Social Participation. Yogyakarta: PAU-SS UGM. 2002.

[3] Mardikanto, Totok and Poerwoko Soebiato. Community Empowerment in Public Policy Perspective. Bandung : Alfabeta. 2015.

[4] Ahmad, Jamaluddin. Research Methods in Public Administration Theory and Applications. Yogyakarta: Gava Media. 2015. 